\title{
Population density of Tibraca limbativentris on flood irrigated rice and alternative host plants
}

\author{
Mauricio Paulo Batistella Pasini(1), Alessandro Dal'Col Lúcio(2), Alberto Cargnelutti Filho(2), \\ Ana Lúcia de Paula Ribeiro( ${ }^{(3)}$, João Fernando Zamberlan ${ }^{(1)}$ and Sidinei José Lopes ${ }^{(2)}$
}

\begin{abstract}
(1)Universidade de Cruz Alta, Rodovia Municipal Jacob Della Méa, Km 5.6, Parada Benito, CEP 98005-972 Cruz Alta, RS, Brazil. E-mail: mpasini@unicruz.edu.br, jfzamberlan@unicruz.edu.br (2)Universidade Federal de Santa Maria, Avenida Roraima, no 1.000, Cidade Universitária, Camobi, CEP 97105-900 Santa Maria, RS, Brazil. E-mail: adlucio@ufsm.br, alberto.cargnelutti.filho@gmail.com, sjlopes2008@gmail.com ${ }^{(3)}$ Instituto Federal de Educação, Ciência e Tecnologia Farroupilha, Campus São Vicente do Sul, Rua 20 de Setembro, no 2.616, CEP 97420-000 São Vicente do Sul, RS, Brazil. E-mail: analucia.ribeiro@iffarroupilha.edu.br
\end{abstract}

\begin{abstract}
The objective of this work were to evaluate the population dynamics of the rice stem bug (Tibraca limbativentris) around and in flood irrigated rice cultivation area, to quantify the insect population flow between crops and host plants, and to determine the effect of the species, the diameter of the plant, and the distance of the host plant from the border on the rice stem bug population. The work was conducted in the 2012/2013 harvest and in the off-season, with sampling of rice, Andropogom bicornis, and Andropogon lateralis plants in six cultivated areas, in order to count the number of insects. The population density of the rice stem bug in irrigated rice and alternative host plants presents spatial and temporal dependence. In the cultivated areas, the population density of the rice stem bug increases according to the evolution of the rice phenological stages, with the highest densities concentrated in regions close to the crop borders. The diameter and species of the host plant affect the rice stem bug population. Andropogon bicornis plants have higher population densities than $A$. lateralis, and plants with larger diameters show higher population densities of the rice stem bug. In the off-season, the greatest population of the rice stem bug on host plants is concentrated up to $45 \mathrm{~m}$ from the crop border, but it can disperse until $150 \mathrm{~m}$.
\end{abstract}

Index terms: Oryza sativa, geostatistics, population dynamics, quiescence, rice stem bug.

\section{Densidade populacional de Tibraca limbativentris em arroz irrigado por inundação e plantas hospedeiras alternativas}

\begin{abstract}
Resumo - O objetivo deste trabalho foi avaliar a dinâmica populacional do percevejo-do-colmo (Tibraca limbativentris) no entorno e na área de cultivo de arroz irrigado por inundação, quantificar o fluxo populacional do percevejo entre lavouras e plantas hospedeiras, e determinar a influência da espécie, do diâmetro da planta e da distância da planta hospedeira da bordadura sobre a população do percevejo-do-colmo. O trabalho foi conduzido na safra 2012/2013 e na entressafra, com amostragem de plantas de arroz, Andropogom bicornis e A. lateralis em seis áreas de cultivo, para a contagem do número de insetos. A densidade populacional do percevejo-do-colmo em arroz irrigado e plantas hospedeiras alternativas apresenta dependência espacial e temporal. Nas áreas de cultivo, a densidade populacional do percevejo-do-colmo aumenta de acordo com a evolução dos estádios fenológicos do arroz, com as maiores densidades concentradas em regiões próximas às suas bordaduras. $\mathrm{O}$ diâmetro e a espécie da planta hospedeira influenciam a população do percevejodo-colmo. Andropogon bicornis apresenta maiores densidades populacionais que A. lateralis e plantas com maiores diâmetros apresentam maiores densidades populacionais do percevejo-do-colmo. Durante a entressafra, a maior população do inseto em plantas hospedeiras se concentra até $45 \mathrm{~m}$ da bordadura, mas é capaz de se dispersar até $150 \mathrm{~m}$.
\end{abstract}

Termos para indexação: Oryza sativa, geoestatística, fluxo populacional, quiescência, percevejo-do-colmo.

\section{Introduction}

The rice stem bug [Tibraca limbativentris Stål 1860 (Hemiptera: Pentatomidae)] is one of the main pests of the rice (Oriza sativa L.) crop with major importance for irrigated rice (Machado et al., 2014). In Brazil, it is the second insect-pest on an economic scale in the state of Rio Grande do Sul (Reunião Técnica da Cultura do Arroz Irrigado, 2014). The damage caused by this insect produces two symptoms: white panicle and dead heart, with direct interference on yield and damages that are proportional to its population density 
(Trujillo, 1970; Pazini et al., 2015), which is subject to spatial and temporal variability.

In the off-season, these insects look for alternative habitats around the cultivated areas to find shelter, where they remain in quiescence (Medeiros \& Megier, 2009; Smaniotto \& Panizzi, 2015). Quiescent adults leave their shelter in late September and early October, when they seek host plants and copulate (Ferreira et al., 1997). With the sowing of rice and seedling emergence, the bugs migrate to the crops and continue their physiological activities until harvest, after which they migrate to the surroundings of the cultivated areas (Klein et al., 2012; Awuni et al., 2015).

The vegetation of the areas surrounding the crops, in temperate and cold regions, offers microclimatic conditions ideal for insect survival, especially for those that enter into quiescence (Dennis et al., 1994). These sites of aggregation and quiescence interact with the cultivated areas and influence the spatial distribution of the rice stem bug (Trujillo, 1970). Pasini et al. (2015) observed that, in the off-season, the species of host plants Andropogon bicornis L. and A. lateralis Nees are used for the maintenance of the insect population, whose density is affected by plant diameter.

Studies on the population dynamics of pest insects help to better understand population biology and to develop sampling procedures and integrated management strategies. Geostatistics represents a valuable set of statistical tools to investigate the spatial pattern of pests and to support the practice of integrated management (Sciarretta \& Trematerra, 2014); therefore, it is important for establishing insect population dynamics (Duan et al., 2015).

Populations of insect pests in crops can be estimated using interpolation procedures, which allow generating continuous surfaces through specific sampling units (Soares et al., 2008; Duarte et al., 2015). Among the interpolation methods, ordinary kriging is one of the most used (Sciarretta \& Trematerra, 2014; Rosado et al., 2015). In it, theoretical semivariogram models are fit to the experimental ones, in order to find the best model - with the smallest errors - for each data set (Pasini et al., 2014).

The use of this interpolation procedure during the off-season and at different stages of crop development allows elucidating how the pest insect disperses in the cultivated areas, characterizing their population dynamics (Sciarretta \& Trematerra, 2014; Rosado et al., 2015).

The objective of this work was to evaluate the population dynamics of the rice stem bug around and in flood irrigated rice cultivation area, to quantify the insect population flow between crops and host plants, and to determine the effect of the species, the diameter of the plant, and the distance of the host plant from the border on the rice stem bug population.

\section{Materials and Methods}

The experiment was performed in the municipality of Santa Maria, in the state of Rio Grande do Sul, Brazil (785108 m; 6716393 m, 21J, UTM), in six flood irrigated rice crops with areas between 0.25 and 14.1 ha (Figure 1), cultivated according to the technical recommendations for the culture (Reunião Técnica da Cultura do Arroz Irrigado, 2014), but without the application of chemical pesticides. Herbaceous vegetation was found to the east, west, and south of the cultivated areas and between crops, with the predominance of species of the families: Poaceae, Andropogon bicornis, A. lateralis, and Saccharum angustifolium (Nees) Trin.; Apiaceae, Eryngium horridum Malme; and Cyperaceae. The northern limit of the cultivated area was characterized by the presence of shrub and tree species (Boldrini, 2009). The local climate, according to Köppen's classification, is Cfa, humid subtropical with no defined dry season and with hot summers (Heldwein et al., 2009).

In each crop, a grid of $30 \times 30 \mathrm{~m}$ was used for sampling of insects; each host plant was considered a sampling unit, where the number of insects was counted. A total of 39 sampling units were originated in crop 1, 192 in crop 2, 143 in crop 3, 385 in crop 4, 13 in crop 5, and 30 in crop 6 (Figure 1). In each sampling unit, an average of 200 plants was sampled in $1 \mathrm{~m}^{2}$ (50 plants per meter row, at a spacing of $0.20 \mathrm{~m}$ between rows). The number of rice stem bug individuals obtained by direct counting within the units, as well as the total number of individuals per square meter (200 plants), were used in the data analysis. Around the areas, 204 host plants, with diameters of $25 \pm 5 \mathrm{~cm}$, were selected; of these, 104 were of the species A. bicornis and 100 of $A$. lateralis.

The following evaluations were conducted in the offseason of 2012, at pre-seeding in 2012, and at harvest 
in 2012/2013: A1, in the V3 stage, corresponding to the collar formed in the third leaf of the main stem; A2, in the V6 stage, corresponding to the collar formed in the sixth leaf of main stem; A3, in the V9 stage, corresponding to the collar formed in the ninth leaf of the main stem and to the beginning of panicle development; A4, in the R2 stage, corresponding to the formation of the collar of the flag leaf; A5, in the R4 stage, corresponding to anthesis; A6, in the R6 stage, corresponding to the elongation of one or more grains in the shell; and A7, in the R9 stage, corresponding to the complete maturity of the grains in the panicle (Counce et al., 2000). In addition, three more evaluations were carried out in the off-season of 2013, totaling ten evaluations.

In the alternative host plants, two samplings were performed. The first in the surroundings of crops 1 to 4, at equivalent times; the experimental units (EUs) selected were $A$. bicornis and A. lateralis (Poaceae) plants with diameters of $0.10,0.20,0.30,0.40$, and $0.50 \mathrm{~m}$, located up to $15 \mathrm{~m}$ from the crop border. Plant species and diameter were evaluated in all four crops: 2 species $\mathrm{x} 5$ diameters $\mathrm{x} 8$ replicates. The second sampling was carried out every $15 \mathrm{~m}$ from the crop border, on $A$. bicornis and $A$. lateralis plants, with $0.25 \pm 5 \mathrm{~cm}$ diameter, totaling ten evaluation bands up to $150 \mathrm{~m}$ from the border. In crops 3 and 4, the evaluations were done in the 2012 and 2013

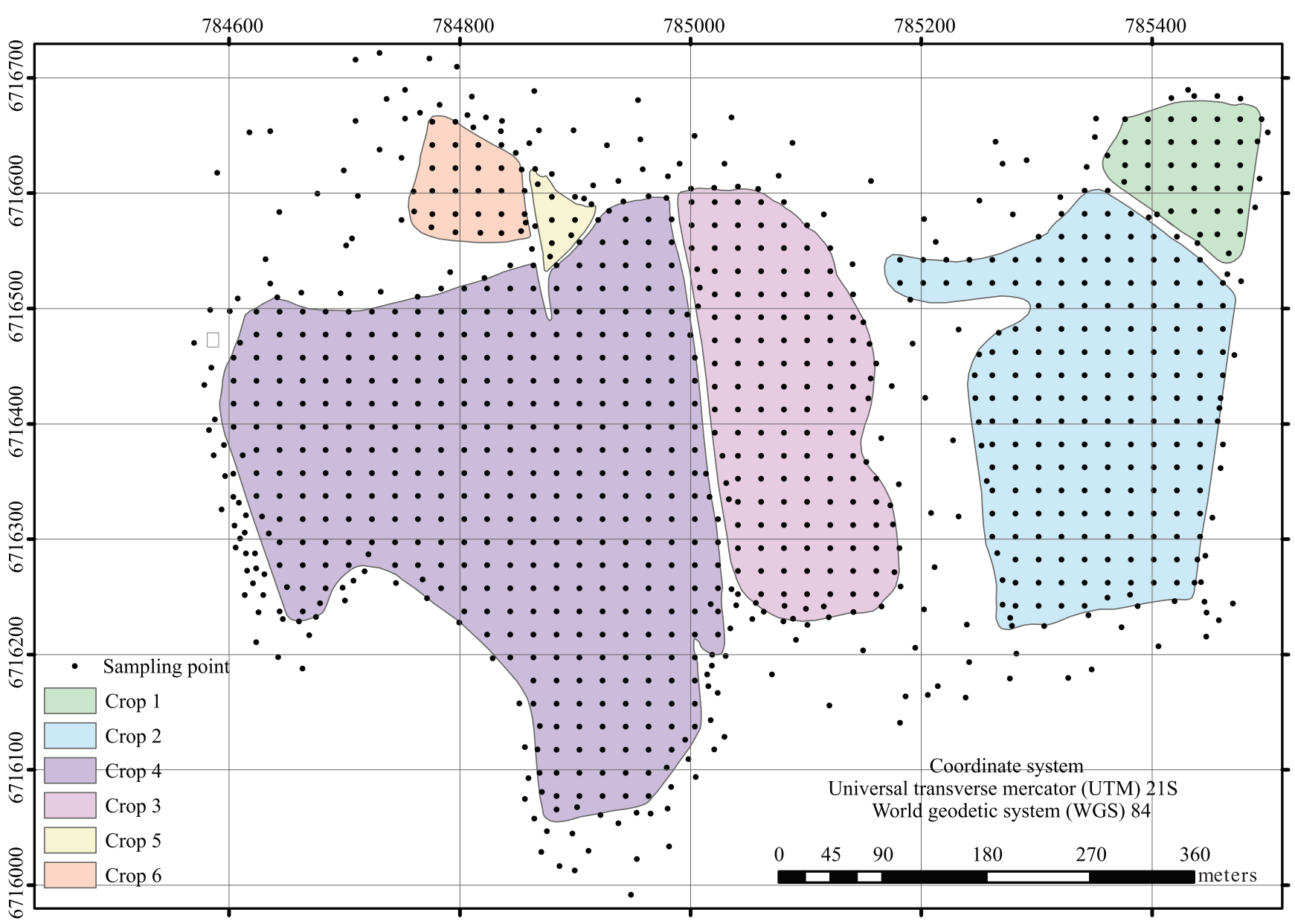

Figure 1. Map of the study area, with representation of the sampling points in the six flood irrigated rice (Oryza sativa) crops evaluated. The points out of the limits of the crops represent the samples obtained from alternative host plants in the crop surroundings. Crop 1, area of 1.3 ha and perimeter of $459 \mathrm{~m}$; crop 2, area of 6.92 ha and perimeter of 1,252 m; crop 3 , area of 4.91 ha and perimeter of $963 \mathrm{~m}$; crop 4, area of 14.11 ha and perimeter of $1,819 \mathrm{~m}$; crop 5, area of $0.25 \mathrm{ma}$ and perimeter of $233 \mathrm{~m}$; and crop 6, area of 0.86 ha and perimeter of $356 \mathrm{~m}$. 
off-seasons. In each crop and off-season, 160 EUs were evaluated: 10 bands $\mathrm{x} 2$ plant species $\mathrm{x} 8$ replicates. The individuals were screened and quantified for each EU.

For the data analysis on host plants, the number of insects obtained in the EUs of the cultivated areas and their surroundings was organized using the descriptive statistics mean and standard deviation.

In the first sampling, on crops 1 and 4 , the number of insects on the plants surrounding the crops was analyzed in a $2 \times 5$ (species $\mathrm{x}$ diameters) factorial arrangement, in a completely randomized design, with eight replicates, totaling 80 EUs. In the second sampling, on crops 3 and 4 , the number of insects on the plants at specific distances from the border was determined in a 2x10 (species $\mathrm{x}$ band) factorial arrangement, also in a completely randomized design, with eight replicates, totaling 160 EUs.

In both analyses, the normality of the data and homogeneity of variances were checked with the Anderson-Darling and Bartlett tests, respectively. When these assumptions were not met, the data were transformed using $\sqrt{\mathrm{x}+0.5}$. The variance and regression analyses for plant diameters and distances of the bands were performed with Microsoft Excel, version 2010 , at $5 \%$ probability.

Population flow data were determined based on the evaluations carried out in the surroundings and cultivated areas of crops 1 to 4 , then were used to make graphs. The values obtained for the host plants from crop surroundings were transformed using $f(x)=x / 0.04906$ for number of adults per square meter of host plant. The value 0.04906 corresponds to the area of a plant with a diameter of $0.25 \mathrm{~m}$.

For the spatial variability analysis, the number of adult rice stem bugs on the host plant in the sampling grids in crops 1 to 6 and their surroundings was taken into account (Figure 1). The values obtained for the host plants from crop surroundings were transformed using $\mathrm{f}(\mathrm{x})=\mathrm{x} / 0.04906$. Then, the data were subjected to the geostatistical analysis in order to verify the existence of spatial dependence; if existent, its degree was quantified by comparing the models to the isotropic experimental semivariogram, estimated by:

$$
\gamma(h)=\frac{1}{2 N(h)} \sum_{i=1}^{N(h)}\left[Z\left(X_{i}\right)-Z\left(x_{i}+h\right)\right]^{2}
$$

where $(\gamma)$ is the semivariance and $\mathrm{N}(\mathrm{h})$ is the number of $\mathrm{Z}\left(\mathrm{x}_{\mathrm{i}}\right)$ and $\mathrm{Z}\left(\mathrm{x}_{\mathrm{i}}+\mathrm{h}\right)$ pairs measured, separated by an $h$ vector. From the experimental semivariograms, the following 11 theoretical models were adjusted (Johnston et al., 2001) circular, spherical, tetraspherical, pentaspherical, exponential, Gaussian, rational quadratic, hole effect, k-Bessel, j-Bessel and stable, respectively, through the equations:

$$
\gamma(\mathrm{h})=\frac{2 \mathrm{C}_{0}+\mathrm{C}_{1}}{\pi}\left[\frac{\mathrm{h}}{\mathrm{a}} \sqrt{1-\left(\frac{\mathrm{h}}{\mathrm{a}}\right)^{2}+\arcsin \frac{\mathrm{h}}{\mathrm{a}}}\right]
$$

for $0 \leq \mathrm{h} \leq \mathrm{a}$, and $\gamma(\mathrm{h} ; \theta)=\mathrm{C}_{0}+\mathrm{C}_{1}$ for $\mathrm{a}<\mathrm{h}$;

$$
\gamma(\mathrm{h})=\mathrm{C}_{0}+\mathrm{C}_{1}\left[\frac{3}{2} \frac{\mathrm{h}}{\mathrm{a}}-\frac{1}{2}\left(\frac{\mathrm{h}}{\mathrm{a}}\right)^{3}\right]
$$

for $0 \leq \mathrm{h} \leq \mathrm{a}$, and $\gamma(\mathrm{h} ; \theta)=\mathrm{C}_{0}+\mathrm{C}_{1}$ for $\mathrm{a}<\mathrm{h}$;

$$
\gamma(\mathrm{h})=\frac{2 \mathrm{C}_{0}+\mathrm{C}_{1}}{\pi}\left[\begin{array}{l}
\arcsin \left(\frac{\mathrm{h}}{\mathrm{a}}\right)+\sqrt{1-\left(\frac{\mathrm{h}}{\mathrm{a}}\right)^{2}}+ \\
\frac{2}{3} \frac{\mathrm{h}}{\mathrm{a}}\left(1-\left(\frac{\mathrm{h}}{\mathrm{a}}\right)^{2}\right)^{\frac{3}{2}}
\end{array}\right]
$$

for $0 \leq \mathrm{h} \leq \mathrm{a}$, and $\gamma(\mathrm{h} ; \theta)=\mathrm{C}_{0}+\mathrm{C}_{1}$ for $\mathrm{a}<\mathrm{h}$;

$$
\gamma(\mathrm{h})=\mathrm{C}_{0}+\mathrm{C}_{1}\left[\frac{15}{8} \frac{\mathrm{h}}{\mathrm{a}}-\frac{5}{4}\left(\frac{\mathrm{h}}{\mathrm{a}}\right)^{3}+\frac{3}{8}\left(\frac{\mathrm{h}}{\mathrm{a}}\right)^{5}\right]
$$

for $0 \leq \mathrm{h} \leq \mathrm{a}$, and $\gamma(\mathrm{h} ; \theta)=\mathrm{C}_{0}+\mathrm{C}_{1}$ for $\mathrm{a}<\mathrm{h}$;

$$
\gamma(\mathrm{h})=\mathrm{C}_{0}+\mathrm{C}_{1}\left[1-\mathrm{e}^{-3\left(\frac{\mathrm{h}}{\mathrm{a}}\right)}\right]
$$

for all h;

$$
\gamma(\mathrm{h})=\mathrm{C}_{0}+\mathrm{C}_{1}\left[1-\mathrm{e}^{-3\left(\frac{\mathrm{h}}{\mathrm{a}}\right)^{2}}\right]
$$

for all $\mathrm{h}$;

$$
\gamma(\mathrm{h})=\mathrm{C}_{0}+\mathrm{C}_{1} \frac{19\left(\frac{\mathrm{h}}{\mathrm{a}}\right)^{2}}{1+19\left(\frac{\mathrm{h}}{\mathrm{a}}\right)^{2}}
$$

for all $\mathrm{h} ; 0$ for $\mathrm{h}=0$ and

$$
\gamma(\mathrm{h})=\mathrm{C}_{0}+\mathrm{C}_{1} \frac{1-\sin (2 \pi \mathrm{h})}{\sin \left(\frac{2 \pi \mathrm{h}}{\mathrm{a}}\right)}
$$

for $\mathrm{h} \neq 0$; 


$$
\gamma(\mathrm{h})=\mathrm{C}_{0}+\mathrm{C}_{1}\left[1-\frac{\left(\frac{\Omega_{\theta_{\mathrm{k}}} \mathrm{h}}{\mathrm{a}}\right)^{\theta_{\mathrm{K}}}}{2^{\theta_{\mathrm{k}}-1} \Gamma\left(\theta_{\mathrm{K}}\right)} \mathrm{K}_{\theta_{\mathrm{K}}}\left(\frac{\Omega_{\theta_{\mathrm{K}}} \mathrm{h}}{\mathrm{a}}\right)\right]
$$

for all h, where $\Omega_{\theta \mathrm{k}}$ is a value found numerically so that $\gamma(\mathrm{a})-0.95\left(\mathrm{C}_{0}+\mathrm{C}_{1}\right)$ for any $\theta_{\mathrm{k}}, \gamma\left(\theta_{\mathrm{k}}\right)$ is the gamma function,

$$
\Gamma(\mathrm{y})=\int_{0}^{\infty} \mathrm{x}^{\mathrm{y}-1} \exp (-\mathrm{x}) \mathrm{dx}
$$

and $\mathrm{K}_{\theta \mathrm{k}}$ is the modified Bessel function of the second kind of order $\theta_{\mathrm{k}}$; j-Bessel,

$$
(h)=C_{0}+C_{1}\left[1-\frac{2^{\theta_{d}} \Gamma\left(\theta_{d}+1\right)}{\left(\frac{\Omega_{\theta_{d}}}{a}\right)^{\theta_{d}}} J_{\theta_{d}}\left(\frac{\Omega_{\theta_{d}} h}{a}\right)\right]
$$

for all $\mathrm{h}$, where $\mathrm{C}_{0}+\mathrm{C}_{1} \geq 0, \mathrm{a} \geq 0, \theta \geq 0, \Omega_{\theta \mathrm{d}}$ must satisfy $B=a, B>0, \gamma(B)=C_{0}+C_{1}, \gamma(B)=C_{0}+C_{1}$, $\gamma^{\prime}(B)<0$, and $\mathbf{J}_{\theta \mathrm{d}}$ is the $\mathrm{j}$-Bessel function; and

$$
\gamma(\mathrm{h})=\mathrm{C}_{0}+\mathrm{C}_{1}\left[1-\mathrm{e}^{\left(-3\left(\frac{\mathrm{h}}{\mathrm{a}}\right)^{\theta_{\mathrm{e}}}\right)}\right]
$$

for all $\mathrm{h}$, where $\mathrm{C}_{0}+\mathrm{C}_{1}$ and $0 \leq \theta$ and $\leq 2$. The equations were estimated according to Johnston et al. (2001) with the aid of the ArcGis, version 9.2, software (Environmental Systems Research Institute, Redlands, CA, USA).

Using the algorithm of weighted least squares, these models were adjusted to the experimental semivariogram, and the following model parameters were defined: nugget effect $(\mathrm{C} 0)$, which corresponds to the discontinuity of the semivariogram for distances smaller than those of the samples; sill $(\mathrm{C} 0+\mathrm{Cl})$, which corresponds to the total variance of the values sampled; and range (a), which corresponds to the distance at which the samples are spatially correlated (Yamamoto \& Landim, 2013).

In order to verify the existence of spatial dependence, the spatial dependence index (SDI) was applied, which is the ratio representing the percentage of data variability explained by spatial dependence. The SDI is estimated with the expression $\mathrm{SDI}=[\mathrm{Cl} /(\mathrm{C} 0+$ C1)]100, being classified as: strong, when $\mathrm{SDI}>75 \%$; medium, when $25<\mathrm{SDI} \leq 75 \%$; and low, when $\mathrm{SDI} \leq 25 \%$
(Zimback, 2001). After the confirmation of spatial dependence, inferences were performed by ordinary kriging, which allowed for the estimation of values at sites not evaluated.

The semivariogram model was selected according to the Webster \& Oliver (2007) cross-validation technique, by comparing the impact of interpolators among the real and estimated values, in which the model with more accurate predictions is chosen.

As the first indicator of cross-validation, the mean prediction error was used:

$$
\overline{\mathrm{E}}=\frac{\sum_{\mathrm{i}=1}^{\mathrm{n}}\left[\hat{\mathrm{Z}}\left(\mathrm{S}_{\mathrm{i}}\right)-\mathrm{Z}\left(\mathrm{S}_{\mathrm{i}}\right)\right]}{\mathrm{n}}
$$

where $\hat{Z}\left(\mathrm{~S}_{\mathrm{i}}\right)$ is the observed value and $\mathrm{Z}\left(\mathrm{S}_{\mathrm{i}}\right)$ is the estimated value.

The second indicator was the root-mean-square prediction (RMS) error:

$$
\mathrm{RMS}=\sqrt{\frac{\sum_{\mathrm{i}=1}^{\mathrm{n}}\left[\hat{\mathrm{Z}}\left(\mathrm{S}_{\mathrm{i}}\right)-\mathrm{Z}\left(\mathrm{S}_{\mathrm{i}}\right)\right]^{2}}{\mathrm{n}}}
$$

The third indicator was the root-mean-square standardized prediction (RMSS) error:

$$
\mathrm{RMSS}=\sqrt{\frac{\sum_{\mathrm{i}=1}^{\mathrm{n}}\left[\left(\hat{\mathrm{Z}}\left(\mathrm{S}_{\mathrm{i}}\right)-\mathrm{Z}\left(\mathrm{S}_{\mathrm{i}}\right)\right) / \hat{\sigma}\left(\mathrm{S}_{\mathrm{i}}\right)\right]^{2}}{\mathrm{n}}}
$$

It should be noted that the best adjustments are obtained when indicators $\overline{\mathrm{E}}$ and RMS are close to 0 and RMSS is close to 1 .

The cross-validation grades for the indicators varied from 1 to 3 , according to the selected criterion for each indicator: for RMSS, values closer to 1 received grade 3 , whereas the most distant values received grade 1 . For the estimates $\overline{\mathrm{E}}$ and RMS, values closer or equal to zero received grade 3 , and the most distant values received grade 1 . The model with the highest sum of grades was chosen.

To represent the dispersion of the rice stem bug at various development stages and cultivation areas, maps were generated from the estimates - which were assigned different colors - obtained by the best interpolation, at intervals defined by integer isolines. The Universal Transverse Mercator coordinate system in the World Geodetic System 84 datum was adopted. For the preparation of the maps and geostatistical analysis, the ArcGis, version 9.3, software 
(Environmental Systems Research Institute, Redlands, CA, USA) was used.

\section{Results and Discussion}

The rice stem bug population showed similar behavior on crops 1 to 4, with no individuals found in the 2012 and 2013 off-seasons and at pre-seeding. In the first evaluations, the insect population was smaller, but gradually increased with the evolution of the vegetative stages of the rice plant, regardless of the evaluated crop. However, in alternative host plants, the population showed a behavior contrary to that observed in the cultivated areas. In A. bicornis and $A$. lateralis plants, the largest populations were found in off-season evaluations, decreasing at pre-seeding; in the V3 to R4 development stages of rice, the number of individuals per plant was less than one, increasing in the R6 and R9 stages (Counce et al., 2000).

In Figure 2, the population densities observed in the alternative host plants were grouped with those of the cultivated areas. In the alternative host plants, the population density tended to decrease with the beginning of rice cultivation, whereas, in the cultivated areas, the density tended to increase, reaching its peak in R6; from this stage onwards, there was an inversion of the population flow, in which the insects migrated to the environment.

In the off-season, the rice stem bug searches for host plants to find shelter around the growing areas, where they remain in quiescence (Panizzi, 2015). With the increase in air temperature starting in August, the adult insects leave their shelter at the end of September and search for host plants in order to copulate. With rice emergence, the rice stem bug disperses to the cultivated area due to the greater availability of food (Krinski \& Foerster, 2017). Because of its high biotic potential, this insect population completes up to three generations in the cultivated area, increasing markedly and reaching its peak in the $\mathrm{R} 6$ and $\mathrm{R} 9$ rice stages. In these stages, plants become less palatable to the rice stem bug and the number of unsuccessful test bites increases (Ferreira et al., 1997). This stress condition interferes with population flow, forcing the bug to search for food and shelter again around the cultivated area (Howe \& Jander, 2008; Nguyen-Ngoc et al., 2012). After harvest, the individuals that did not migrate during cultivation go to plants around the crop area,
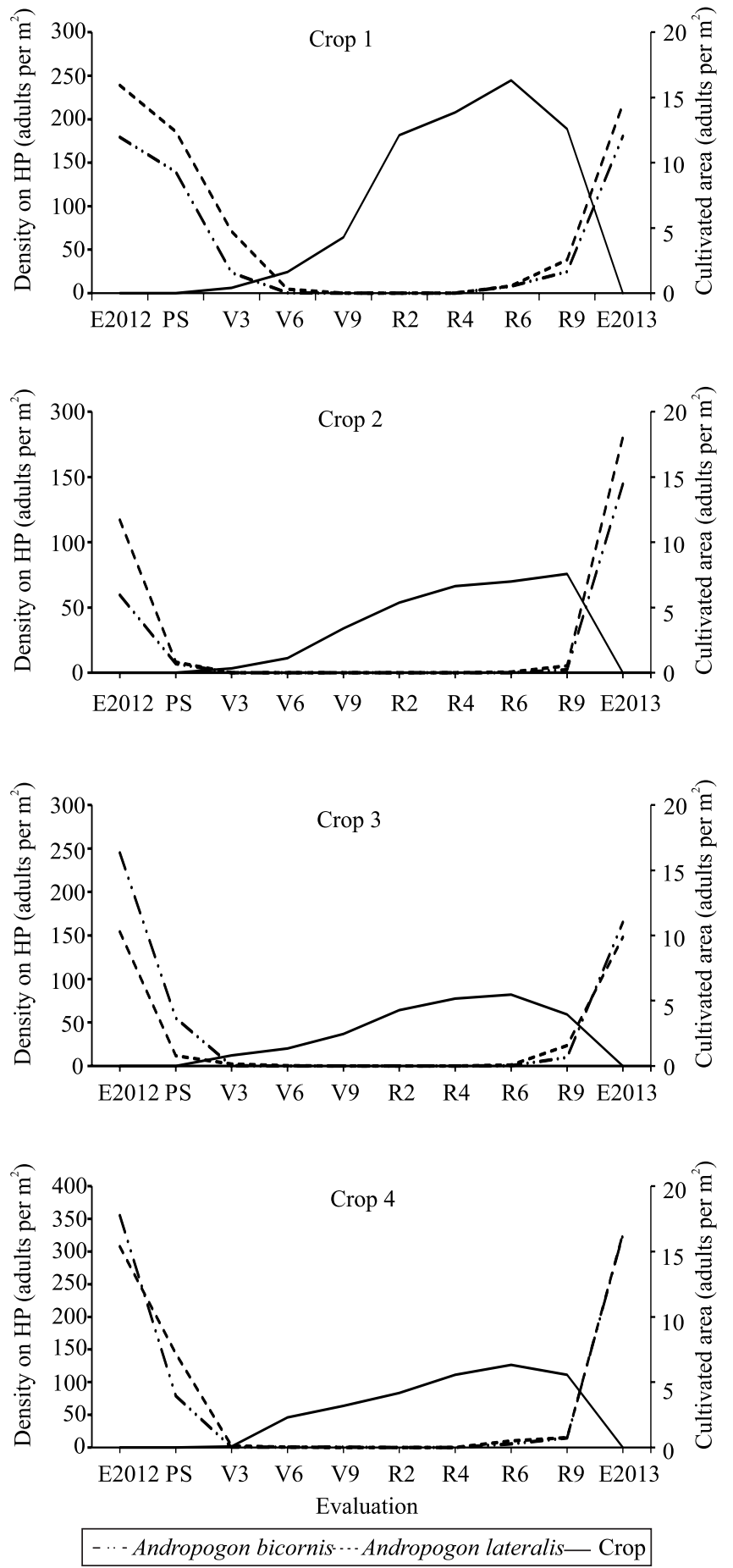

Figure 2. Average density of the rice stem bug (Tibraca limbativentris) on host plants (Hp) Andropogon bicornis and $A$. lateralis in areas cultivated with flood irrigated rice and in their surroundings, in the 2012/2013 harvest. E2012 and E2013, 2012 and 2013 off-seasons; PS, pre-seeding; V3-V9, vegetative stages; and R2-R9, reprodutive stages (Counce et al., 2000). 
where they remain during periods of low temperatures as described by Ferreira et al. (1997).

In the off-season evaluations, for crops 1 to 4 , in most cases, there was an interaction between the host plant species and their respective diameters. An abrupt growth of the rice stem bug population in A. bicornis was verified due to the increase in plant diameter, differing from $A$. lateralis (Figure 3 ). This was the case for the host plants around: crop 1, in the 2012 and 2013 off-seasons, at pre-seeding, and in the V3 stage; crop 2, in the 2012 and 2013 off-seasons; crop 3 , in the 2012 and 2013 off-seasons and at pre-seeding (Figure 4 ); and crop 4, in the 2013 off-season and at pre-seeding. In the surroundings of crop 1, in the R9 stage, and of crop 4, in the 2013 off-season, there was no interaction between the diameter and species of host plant. However, plant diameter had a significant effect on the rice stem bug population (Figure 5).

When the rice stem bug population was evaluated in bands of $15 \mathrm{~m}$ from the border, there was a decrease in the average number of adults per plant in crops 3 and 4, in the 2012 and 2013 off-seasons. The A. bicornis and $A$. lateralis hosts presented mean values between 20 and 50 adults per plant, in the first band, and 1 adult per plant, in the last band, at $150 \mathrm{~m}$ from the border (Figure 6). This result indicates that the population flow was restricted to maximum distances of up to $45 \mathrm{~m}$ from the border.
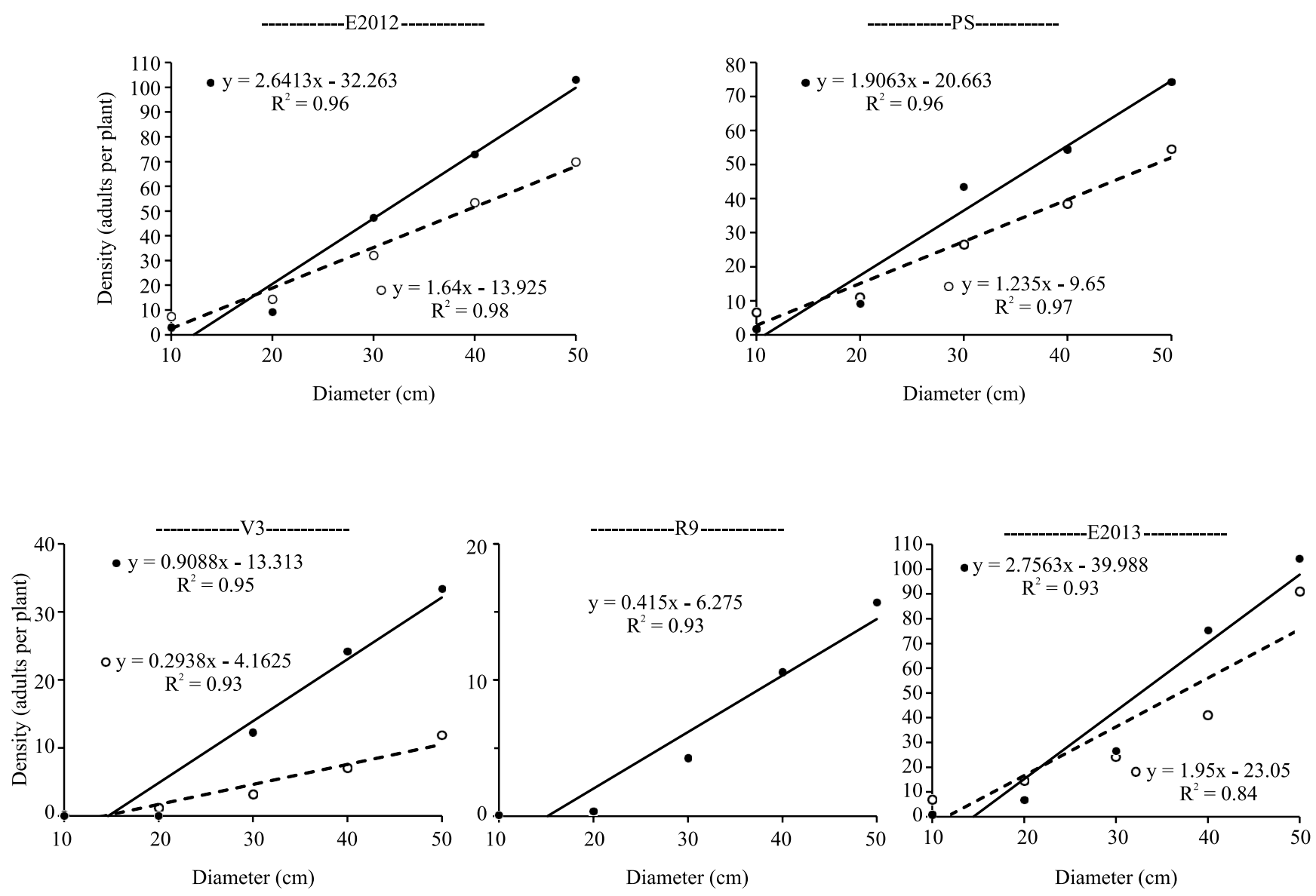

- Andropogon bicornis $\quad$ o Andropogon lateralis

Figure 3. Average density of the rice stem bug (Tibraca limbativentris) in function of the plant diameter of Andropogon bicornis (Ab) and A. lateralis (Al), located around crop 1, in 2012/2013 harvest. E2012 and E2013, 2012 and 2013 off-seasons; PS, pre-seeding; V3-V9, vegetative stages; and R2-R9, reprodutive stages (Counce, et al., 2000). Continuous line and shaded circle indicate $A$. bicornis, and dotted line with circle indicates $A$. lateralis. 
Regarding the geostatistical analyses, in the off-season evaluations, a larger population was observed in 2012 than in 2013. In the evaluation at pre-seeding and during cultivation, the greatest population levels were observed in the R9 stage (A7) (Table 1). This result is related to the high population found in cultivated areas and to the migratory movement of the insects to crop surroundings in search of new host plants.

The average deviation in the number of insects per square meter was higher than the means of the variable in all cases, except for the R4 and R6 stages, showing high data variability. This variability is associated with a large concentration of null values (equal to zero) in the first evaluations. However, with the dispersion of individuals of the rice stem bug, the frequency of null values tends to decrease and there is a better distribution of the obtained values. In the off-season periods, the high values of asymmetry and kurtosis were indicative of the concentration of individuals on the host plants and not in the cultivation areas (Table 1).

For all crops and evaluations, the theoretical models showed spatial dependence, with SDI values above $75 \%$, which can highly contribute to data variability and, therefore, be used for ordinary kriging (OK) interpolation. This way, inferences for the semivariogram theoretical models were made by OK (Zimback, 2001). Using the cross-validation selection

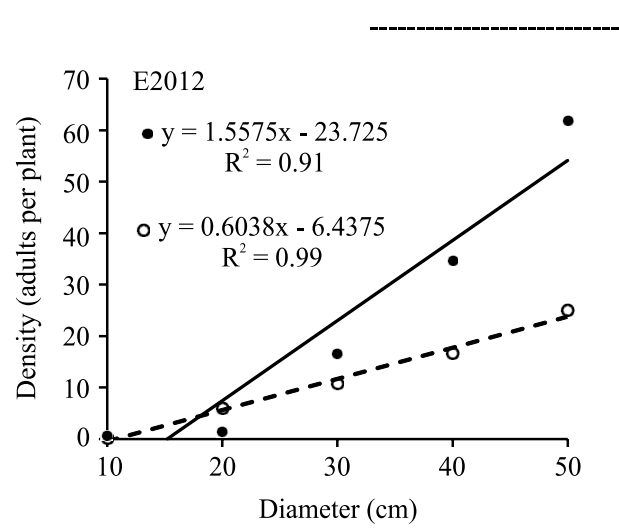

Crop 02
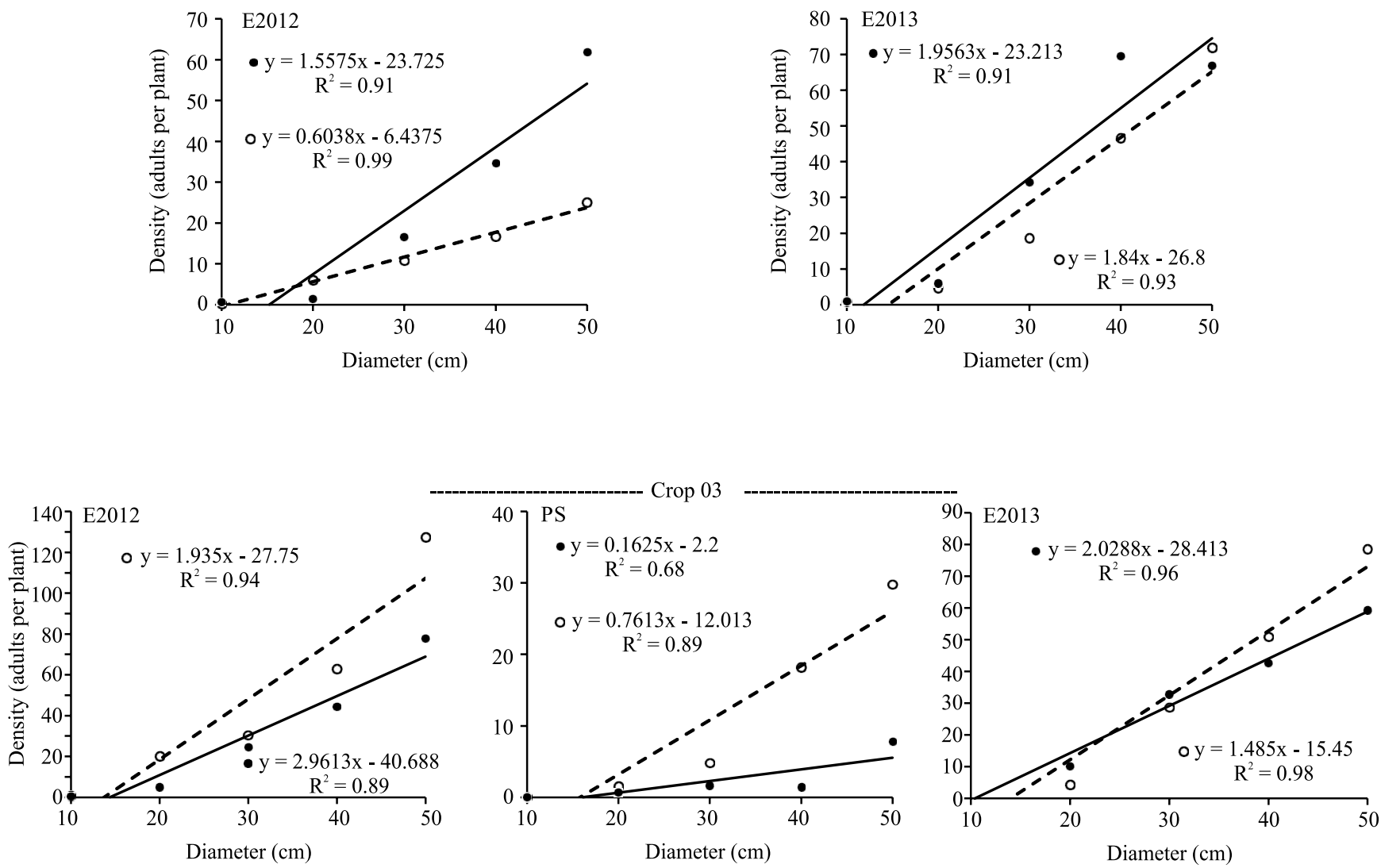

- Andropogon bicornis o Andropogon lateralis

Figure 4. Average density of the rice stem bug (Tibraca limbativentris) in function of the plant diameter of Andropogon bicornis (Ab) and A. lateralis (Al), located around the crops 2 and 3, in the 2012/2013 harvest. E2012, 2012 off-season; PS, pre-seeding; and E2013, 2013 off-season. Continuous line and shaded circle indicate A. bicornis, and dotted line with circle indicates A. lateralis. 

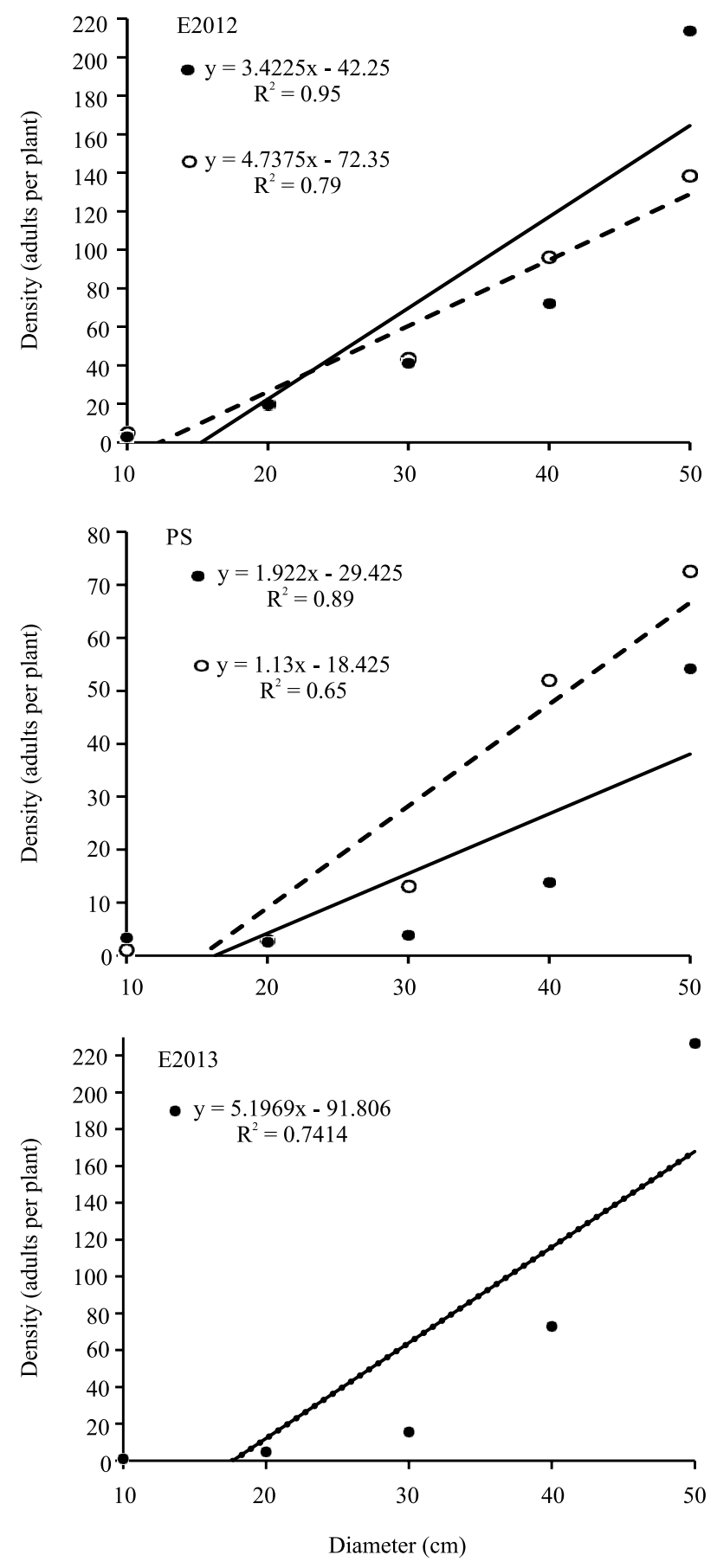

- Andropogon bicornis o Andropogon lateralis

Figure 5. Average density of the rice stem bug (Tibraca limbativentris) in function of the diameter of the host plants Andropogon bicornis (Ab) and A. lateralis (Al), located around crop 4, in the 2012/2013 harvest. E2012, 2012 offseason; PS, pre-seeding; and E2013, 2013 off-season. Continuous line and shaded circle indicate A. bicornis, and dotted line with circle indicates $A$. lateralis.


- Andropogon bicornis o Andropogon lateralis

Figure 6. Average density of the rice stem bug (Tibraca limbativentris) on Andropogon bicornis and A. lateralis in function of the distance from the flood irrigated rice crop border in crops 3 and 4. E2012, 2012 off-season; and E2013, 2013 off-season.

Pesq. agropec. bras., Brasília, v.53, n.3, p.265-278, Mar. 2018 DOI: 10.1590/S0100-204X2018000300001 
criterion (Table 2), ten semivariogram theoretical models were chosen (Table 3). It should be pointed out that different semivariogram models were obtained in the evaluations, which agrees with the hypothesis of Gundogdu \& Guney (2007) that each data set presents a different spatial structure and that it is necessary to define a semivariogram model with the best fit to each one. After the semivariogram theoretical model was selected and the values not sampled by OK were estimated, the spatial distribution maps were generated at intervals defined by integer isolines, which varied according to the population levels determined in each evaluation (Figure 7).

In the 2012 off-season (Figure 7), the spatial distribution of the rice stem bug population was concentrated around the cultivated areas; however, at pre-seeding, the population levels declined. The generated maps also revealed estimation problems, with values overestimated in sites without the presence of insects - in this case, within cultivated areas.

With the sowing of irrigated rice, it was verified that the rice stem bug population was divided into insects that migrated to the cultivated area and that remained on the plant hosts (Figure 7). In the following stages, the rice stem bug population gradually increased and was distributed at a greater concentration at the borders of the cultivated area.

In the R9 stage, there was a reverse flow of the rice stem bug population (Figure 7), with recolonization around the crops, but in smaller populations. Although the choice of the host plant by insects is random, it depends on the distance from the border, with higher concentrations observed at lower distances from the cultivated area (Figure 7). In the spatial distribution maps, similar results were found in the off-season, in sites with the largest population.

With the establishment of the crop, the regions with the largest insect population coincided with those of the host plants with the largest populations in the off-season (Figure 7). According to Ferreira et al. (1997), the dispersion of the rice stem bug occurs by short flights or through the soil; to lay eggs, insects search for host plants the closest possible to food sources, which results in elevated populations in specific regions of the cultivated areas.

This information is important for the establishment of local actions to suppress insect pest populations, considering that knowledge of population flow, together with geostatistics, represents a valuable set of tools to determine the pattern of spatio-temporal variability (Sciarretta \& Trematerra, 2014). Once this pattern and the respective population dynamics are identified, suppressive actions can be taken starting in the off-season, aiming to suppress the insect population on the host plants until crop development, with specific management that would promote a decrease in population density dynamics.

For the maintenance of populations of phytophagous pentatomids, such as the rice stem bug, the successive occurrence of host plants and the presence of a favorable hibernacle are necessary (Panizzi, 1997). A break in this succession can reduce the population of pests in the crops, which would result in a decrease in the number of individuals, reflecting on their ability to infest the crop areas in the following seasons.

Table 1. Descriptive statistics on the number of Tibraca limbativentris (Hemiptera: Pentatomidae) adults per $\mathrm{m}^{2}$, sampled in the off-season 2012 and 2013, in evaluations of flood irrigated rice crops and its surroundings.

\begin{tabular}{|c|c|c|c|c|c|c|c|c|c|c|}
\hline \multirow{2}{*}{ Statistics } & \multicolumn{10}{|c|}{ Rice phenological stage $^{(1)}$} \\
\hline & E2012 & PS & $\mathrm{V} 3$ & V6 & V9 & $\mathrm{R} 2$ & R4 & R6 & R9 & E2013 \\
\hline Average & 20.57 & 10.63 & 0.59 & 1.43 & 2.36 & 3.81 & 5.12 & 5.53 & 11.94 & 18.76 \\
\hline Median & 0 & 0 & 0 & 1 & 1 & 3 & 5 & 4 & 6 & 0 \\
\hline Standard deviation & 46.57 & 26.47 & 1.85 & 1.97 & 2.55 & 4.04 & 4.78 & 5.23 & 19.89 & 42.30 \\
\hline Kurtosis & 4.30 & 6.38 & 36.21 & 2.86 & 0.41 & 2.18 & 1.25 & 0.84 & 9.25 & 3.92 \\
\hline Asymmetry & 2.29 & 2.64 & 5.39 & 1.73 & 1.06 & 1.41 & 1.04 & 1.04 & 3.00 & 2.24 \\
\hline Minimum & 0 & 0 & 0 & 0 & 0 & 0 & 0 & 0 & 0 & 0 \\
\hline Maximum & 254 & 148 & 20 & 11 & 12 & 21 & 26 & 26 & 127 & 183 \\
\hline Sum & 20,814 & 10,758 & 602 & 1,450 & 2,386 & 3,858 & 5,181 & 5,592 & 12,086 & 18,987 \\
\hline Sample unit & 1007 & 1007 & 1007 & 1007 & 1007 & 1007 & 1007 & 1007 & 1007 & 1007 \\
\hline
\end{tabular}

${ }^{(1)}$ E2012 and E2013, 2012 and 2013 off-season; PS, pre-seeding; V3-V9, vegetative stages; and R2-R9, reprodutive stages (Counce et al., 2000). 
Table 2. Cross-validation indicators ${ }^{(1)}$ and grades attributed (in brackets), obtained from ordinary kriging, for the following semivariogram models: C, circular; S, spherical; P, pentaspherical; E, exponential; G, Gaussian; R, rational quadratic; H, hole effect; K, K-Bessel; J, J-Bessel; and St, stable.

\begin{tabular}{|c|c|c|c|c|c|c|c|c|c|c|c|}
\hline Indicator & $\mathrm{C}$ & E & $\mathrm{T}$ & $\mathrm{P}$ & Ex & $\mathrm{G}$ & RQ & $\mathrm{SC}$ & $\mathrm{KB}$ & JB & Es \\
\hline & \multicolumn{11}{|c|}{2012 off-season } \\
\hline & $-0.034(1)$ & $-0.033(2)$ & $-0.0031(3)$ & $-0.026(4)$ & $0.018(9)$ & $-0.007(10)$ & $-0.005(11)$ & $-0.019(8)$ & $-0.022(7)$ & $-0.0023(6)$ & $-0.024(5)$ \\
\hline RMS & $0.311(9)$ & $0.430(7)$ & $0.555(6)$ & $0.633(5)$ & $0.871(4)$ & $0.310(10)$ & $0.221(11)$ & $1.329(1)$ & $0.417(8)$ & $0.948(3)$ & $0.990(2)$ \\
\hline RMSS & $0.728(2)$ & $0.946(9)$ & $0.947(10)$ & $0.945(8)$ & $0.930(7)$ & $0.913(6)$ & $0.984(11)$ & $0.711(1)$ & $0.900(5)$ & $0.855(4)$ & $1.184(3)$ \\
\hline \multirow[t]{3}{*}{$\Sigma$} & 12 & 18 & 19 & 17 & 18 & 33 & 33 & 10 & 20 & 13 & 10 \\
\hline & \multicolumn{11}{|c|}{2012 pre-seeding } \\
\hline & $-0.091(1)$ & $0.088(2)$ & $0.051(5)$ & $-0.022(8)$ & $0.021(9)$ & $0.020(10)$ & $-0.016(11)$ & $-0.071(3)$ & $-0.033(7)$ & $-0.042(6)$ & $-0.063(4)$ \\
\hline RMS & $2.344(1)$ & $2.106(2)$ & $1.909(5)$ & $1.342(8)$ & $1.003(9)$ & $0.899(10)$ & $0.677(11)$ & $2.117(3)$ & $1.769(7)$ & $1.805(6)$ & $1.964(4)$ \\
\hline RMSS & $0.984(8)$ & $1.021(7)$ & $1.209(2)$ & $1.121(3)$ & $1.074(4)$ & $0.997(11)$ & $1.004(10)$ & $1.819(1)$ & $1.111(6)$ & $0.992(9)$ & $1.112(5)$ \\
\hline \multirow[t]{3}{*}{$\Sigma$} & 10 & 11 & 12 & 19 & 22 & 31 & 32 & 7 & 20 & 21 & 13 \\
\hline & & & & & & V3 stage & & & & & \\
\hline & $0.149(5)$ & $0.257(1)$ & $0.240(3)$ & $0.248(2)$ & $0.130(7)$ & $0.037(11)$ & $0.123(9)$ & $0.148(4)$ & $0.137(6)$ & $0.125(8)$ & $0.100(10)$ \\
\hline RMS & $2.646(7)$ & $2.787(3)$ & $2.739(5)$ & $2.777(4)$ & $3.537(1)$ & $1.022(11)$ & $2.643(8)$ & $3.537(1)$ & $2.714(6)$ & $2.495(10)$ & $2.640(9)$ \\
\hline RMSS & $0.920(6)$ & $1.049(7)$ & $1.046(8)$ & $1.936(1)$ & $0.775(4)$ & $1.001(11)$ & $0.758(3)$ & $1.936(1)$ & $0.981(9)$ & $0.805(5)$ & $1.017(10)$ \\
\hline \multirow[t]{3}{*}{$\Sigma$} & 18 & 11 & 16 & 7 & 12 & 33 & 20 & 6 & 21 & 23 & 29 \\
\hline & & & & & & V6 stage & & & & & \\
\hline & $-0.150(1)$ & $-0.051(5)$ & $-0.047(6)$ & $-0.041(7)$ & $-0.014(10)$ & $-0.105(3)$ & $-0.008(11)$ & $-0.138(2)$ & $-0.031(8)$ & $-0.028(9)$ & $-0.105(3)$ \\
\hline RMS & $1.787(11)$ & $1.943(6)$ & 1.994(5) & $2.002(4)$ & $2.097(2)$ & 1.931(7) & $2.241(1)$ & $1.819(10)$ & $1.862(9)$ & $2.019(3)$ & $1.931(7)$ \\
\hline RMSS & $0.963(9)$ & $1.060(7)$ & $1.061(6)$ & $1.051(8)$ & $0.924(5)$ & $1.375(2)$ & $0.995(10)$ & $1.766(1)$ & $1.002(11)$ & $1.315(4)$ & $1.375(2)$ \\
\hline \multirow[t]{3}{*}{$\Sigma$} & 21 & 18 & 17 & 19 & 17 & 12 & 22 & 13 & 28 & 16 & 12 \\
\hline & & & & & & V9 stage & & & & & \\
\hline & $0.072(4)$ & $0.050(10)$ & $0.052(9)$ & $0.053(8)$ & $0.054(7)$ & $0.117(1)$ & $0.077(3)$ & $0.094(2)$ & $0.048(11)$ & $0.065(6)$ & $0.066(5)$ \\
\hline RMS & $1.798(11)$ & $1.872(6)$ & $1.849(7)$ & $1.843(8)$ & $1.873(5)$ & $2.134(2)$ & $1.814(10)$ & $2.155(1)$ & $1.822(9)$ & $1.904(3)$ & $1.884(4)$ \\
\hline RMSS & $0.757(3)$ & $0.863(8)$ & $0.839(6)$ & $0.836(5)$ & $0.802(4)$ & $2.731(1)$ & $0.848(7)$ & $1.766(2)$ & $0.924(10)$ & $0.957(11)$ & $1.088(9)$ \\
\hline \multirow[t]{3}{*}{$\Sigma$} & 18 & 24 & 22 & 21 & 16 & 4 & 20 & 5 & 30 & 20 & 18 \\
\hline & & & & & & R2 stage & & & & & \\
\hline & $0.188(9)$ & $0.212(4)$ & $0.223(2)$ & $0.192(8)$ & $0.141(11)$ & $0.194(6)$ & $0.223(3)$ & $0.357(1)$ & $0.187(10)$ & $0.204(5)$ & $0.193(7)$ \\
\hline RMS & $2.875(6)$ & $2.824(9)$ & $2.801(11)$ & $2.825(8)$ & $2.843(7)$ & $2.887(3)$ & $2.884(2)$ & $3.199(1)$ & $2.820(10)$ & $2.951(4)$ & $2.884(5)$ \\
\hline RMSS & $0.963(8)$ & $0.884(7)$ & $0.835(4)$ & $0.842(5)$ & $0.826(3)$ & $1.031(9)$ & $0.781(2)$ & $1.358(1)$ & $1.028(10)$ & $1.147(6)$ & $1.023(11)$ \\
\hline \multirow[t]{3}{*}{$\Sigma$} & 23 & 20 & 17 & 21 & 21 & 18 & 7 & 3 & 30 & 15 & 23 \\
\hline & & & & & & R4 stage & & & & & \\
\hline & $-0.027(6)$ & $-0.030(3)$ & $-0.029(5)$ & $-0.031(2)$ & $-0.046(1)$ & $-0.001(10)$ & $-0.012(8)$ & $-0.030(4)$ & $0.000(11)$ & $-0.012(7)$ & $-0.002(9)$ \\
\hline RMS & $2.401(7)$ & $2.416(6)$ & $2.432(5)$ & $2.446(4)$ & $2.544(2)$ & $2.399(8)$ & $2.457(3)$ & $2.610(1)$ & $2.387(11)$ & $2.387(11)$ & $2.389(9)$ \\
\hline RMSS & $0.939(7)$ & $0.878(5)$ & $0.873(4)$ & $0.844(2)$ & $0.852(3)$ & $1.048(8)$ & $0.883(6)$ & $0.967(11)$ & $0.962(9)$ & $0.819(1)$ & $0.964(10)$ \\
\hline \multirow[t]{3}{*}{$\Sigma$} & 20 & 14 & 14 & 8 & 6 & 26 & 17 & 16 & 31 & 19 & 28 \\
\hline & & & & & & R6 stage & & & & & \\
\hline & $0.086(3)$ & $0.075(4)$ & $0.071(5)$ & $0.064(7)$ & $0.052(10)$ & $0.070(6)$ & $0.064(8)$ & $0.225(1)$ & $0.049(11)$ & $0.124(2)$ & $0.062(9)$ \\
\hline RMS & $3.579(9)$ & $3.640(7)$ & $3.735(6)$ & $3.840(4)$ & $3.604(8)$ & $3.429(11)$ & $3.845(3)$ & $6.607(1)$ & $3.567(10)$ & $4.613(2)$ & $3.839(5)$ \\
\hline RMSS & $1.124(9)$ & $1.152(6)$ & $1.192(5)$ & $1.235(4)$ & $1.026(10)$ & $1.519(3)$ & $1.126(8)$ & $12.069(1)$ & $1.020(11)$ & $1.655(2)$ & $1.142(7)$ \\
\hline \multirow[t]{3}{*}{$\Sigma$} & 21 & 17 & 16 & 15 & 28 & 18 & 19 & 3 & 32 & 6 & 21 \\
\hline & & & & & & R9 stage & & & & & \\
\hline & $-0.050(7)$ & $-0.048(8)$ & $-0.128(4)$ & $-0.047(9)$ & $-0.041(10)$ & $-0.121(5)$ & $-0.029(11)$ & $-0.216(2)$ & $-0.077(6)$ & $-0.269(1)$ & $-0.129(3)$ \\
\hline RMS & $2.326(8)$ & $2.322(10)$ & $2.341(6)$ & $2.324(9)$ & $2.336(7)$ & $2.826(2)$ & $2.179(11)$ & $2.687(3)$ & $2.569(5)$ & $3.304(1)$ & $2.579(4)$ \\
\hline RMSS & $1.167(6)$ & $1.052(7)$ & $1.497(4)$ & $0.988(10)$ & $0.963(8)$ & $1.483(5)$ & $0.967(9)$ & $1.981(2)$ & $0.994(11)$ & $10.142(1)$ & $1.509(3)$ \\
\hline \multirow[t]{3}{*}{$\Sigma$} & 21 & 25 & 14 & 28 & 25 & 12 & 31 & 7 & 22 & 3 & 10 \\
\hline & \multicolumn{11}{|c|}{2013 off-season } \\
\hline & $0.029(6)$ & $0.018(8)$ & $0.015(9)$ & $0.011(10)$ & $0.000(11)$ & $-0.081(4)$ & $-0.023(7)$ & $-0.096(2)$ & $-0.085(3)$ & $-0.136(1)$ & $-0.080(5)$ \\
\hline RMS & $2.320(4)$ & $2.317(5)$ & $2.315(6)$ & $2.314(7)$ & $2.366(1)$ & $2.199(9)$ & $2.138(11)$ & $3.301(3)$ & $2.326(2)$ & $2.161(10)$ & $2.218(8)$ \\
\hline RMSS & $2.281(4)$ & $2.278(5)$ & $2.277(6)$ & $2.275(7)$ & $2.326(1)$ & $2.163(9)$ & $2.104(11)$ & $3.247(3)$ & $2.287(2)$ & $2.129(10)$ & $2.182(8)$ \\
\hline$\Sigma$ & 10 & 18 & 21 & 24 & 13 & 22 & 29 & 8 & 25 & 21 & 21 \\
\hline
\end{tabular}

${ }^{(1)} \overline{\mathrm{E}}$, mean prediction errors; RMS, root-mean-square prediction errors; RMSS, root-mean-square standardized prediction errors. 

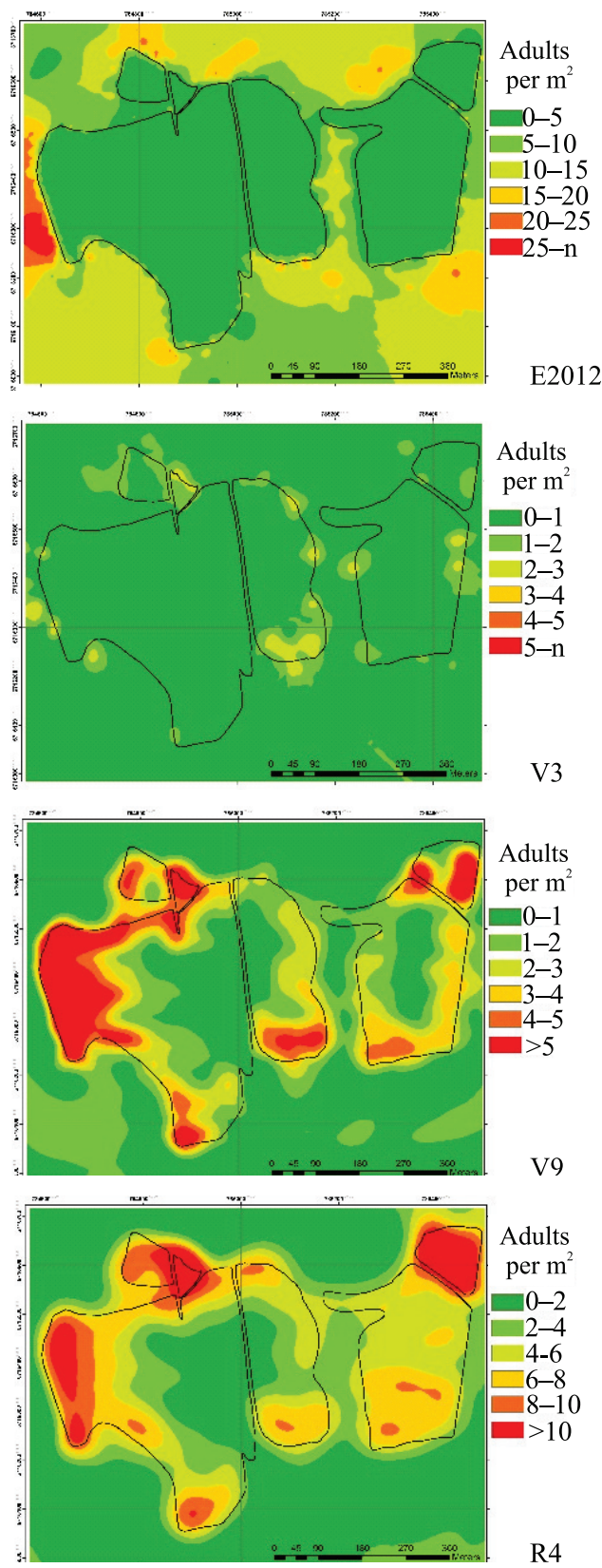

Adults

per $\mathrm{m}^{2}$

0-2

$2-4$

$4-6$
$-6-8$

- $8-10$

$\longrightarrow 10$

R4

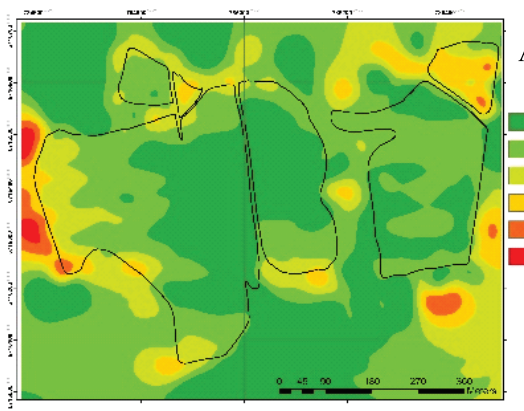

R9

\section{Adults}

per $\mathrm{m}^{2}$

- $0-4$

\begin{tabular}{l}
$4-8$ \\
\hline \\
$8-12$
\end{tabular}

$\square \quad 12-16$
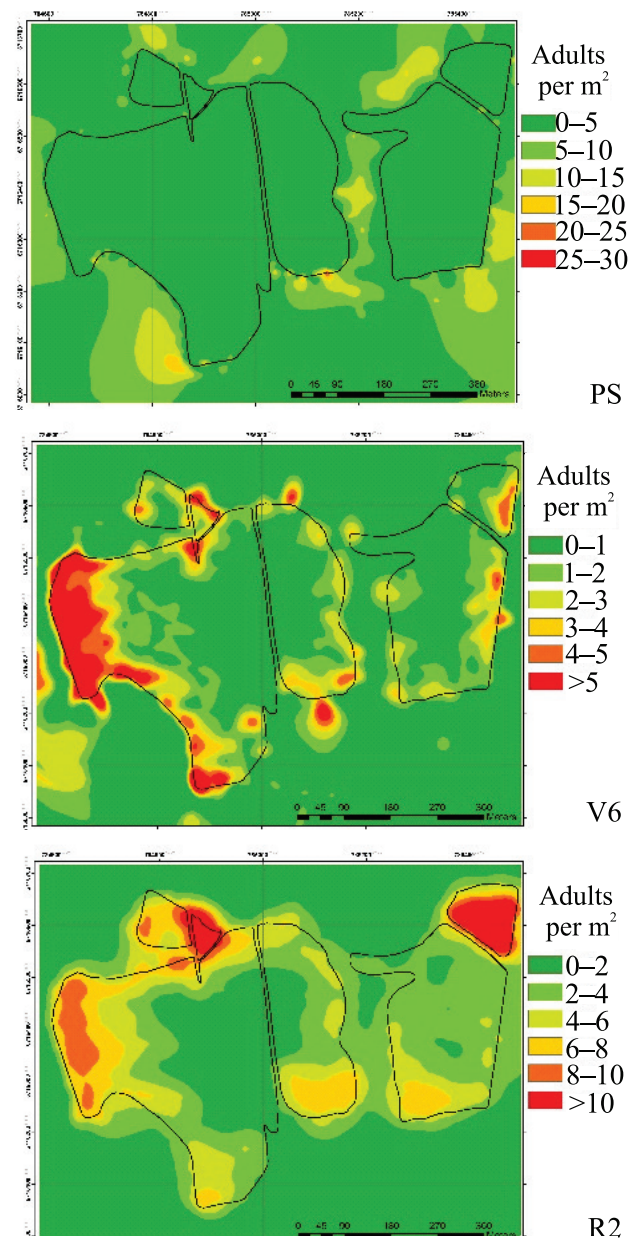

Adults per $\mathrm{m}^{2}$

0-2

$2-4$
$4-6$

-6-8

- $8-10$

$>10$

R2

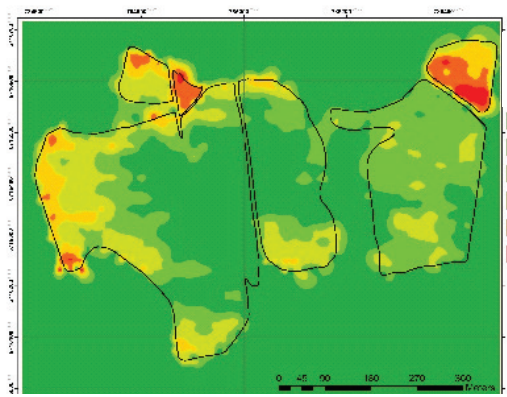

Adults

per $\mathrm{m}^{2}$

- $0-4$

4-8

- 8-12

-12-16

$>20$

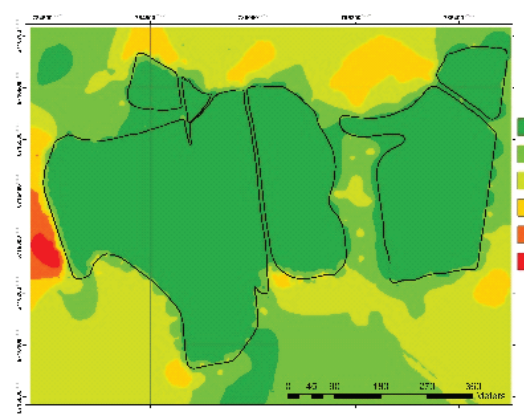

R6

Figure 7. Map of the Tibraca limbativentris spatial distribution of adults per $\mathrm{m}^{2}$ in different evaluations in cultivation areas of flood irrigated rice. E2012 and E2013, 2012 and 2013 off-season; PS, pre-seeding; V3-V9, vegetative stages; and R2-R9, reprodutive stages (Counce et al., 2000). 
Table 3. Nugget effect $\left(\mathrm{C}_{0}\right)$, sill $\left(\mathrm{C}_{1}\right)$, range (a), gamma function $(\Gamma)$, and spatial dependence index (SDI) estimated for the theoretical models of semivariograms used in the different evaluations of Tibraca limbativentris in flood irrigated rice.

\begin{tabular}{|c|c|c|c|c|c|c|}
\hline Evaluation $^{(1)}$ & Model & $\mathrm{C}_{0}$ & $\mathrm{C}_{1}$ & $\mathrm{a}$ & Г & SDI \\
\hline E2012 & Rational quadratic & 405.61 & $1,260.3$ & 144.12 & & 75.67 \\
\hline PS & Rational quadratic & 80.31 & 10.21 & 190.63 & & 35.12 \\
\hline V3 & Gaussiano & 1.06 & 5.67 & 785.14 & & 83.87 \\
\hline V6 & K-Bessel & 0.54 & 3.74 & 664.88 & 0.15 & 87.30 \\
\hline V9 & K-Bessel & 1.01 & 6.28 & 483.07 & 0.20 & 86.16 \\
\hline $\mathrm{R} 2$ & K-Bessel & 3.16 & 12.44 & 335.39 & 0.15 & 79.72 \\
\hline $\mathrm{R} 4$ & K-Bessel & 5.18 & 25.02 & $1,183.10$ & 0.19 & 82.86 \\
\hline R6 & K-Bessel & 6.89 & 27.19 & $1,183.10$ & 0.31 & 83.33 \\
\hline R9 & Rational quadratic & 84.33 & 312.03 & 361.07 & & 78.79 \\
\hline E2013 & Rational quadratic & 303.19 & $1,101.12$ & 116.28 & & 78.41 \\
\hline
\end{tabular}

(1)E2012 and E2013, 2012 and 2013 off-season; PS, pre-seeding; V3-V9, vegetative stages; and R2-R9, reprodutive stages (Counce et al., 2000).

\section{Conclusions}

1. The population density of the rice stem bug (Tibraca limbativentris) in flood irrigated rice (Oryza sativa) and in the alternative host plants Andropogom bicornis and A. lateralis presents spatial and temporal dependence.

2. In the cultivated areas, the population density of the rice stem bug increases according to the evolution of the rice phenological stages, with the highest densities concentrated in the regions close to its borders.

3. The species and diameter of the host plant affect the rice stem bug population, which shows higher density in $A$. bicornis plants, compared with $A$. lateralis, and in plants with larger diameters.

4. The individuals of the rice stem bug disperse up to, at least, $150 \mathrm{~m}$ from the border during the off-season, but concentrate on host plants up to $45 \mathrm{~m}$.

\section{Acknowledgments}

To Conselho Nacional de Desenvolvimento Científico e Tecnológico (CNPq, process numbers 305057/2013-8 and 300663/2013-7), the awards for excellence in research.

\section{References}

AWUNI, G.A.; GORE, J.; COOK, D.; MUSSER, F.; BOND, J. Seasonal abundance and phenology of Oebalus pugnax (Hemiptera: Pentatomidae) on graminaceous hosts in the delta region of Mississippi. Environmental Entomology, v.44, p.931938, 2015. DOI: 10.1093/ee/nvv093.

BOLDRINI, I. A flora dos campos do Rio Grande do Sul. In: PILlAR, V. de P.; MÜLlER, S.C.; CASTILHOS, Z.M. de S.; JACQUES, A.V.A. (Ed.). Campos sulinos: conservação e uso sustentável da biodiversidade. Brasília: Ministério do Meio Ambiente, 2009. p.63-77.

COUNCE, P.A.; KEISLING, T.C.; MITCHELL, A.J. A uniform, objective, and adaptive system for expressing rice development. Crop Science, v.40, p.436-443, 2000. DOI: 10.2135/ cropsci2000.402436x.

DENNIS, P.; THOMAS, M.B.; SOTHERTON, N.W. Structural features of field boundaries which influence the overwintering densities of beneficial arthropod predators. Journal of Applied Ecology, v.31, p.361-370, 1994. DOI: 10.2307/2404550.

DUAN, J.J.; BAUER, L.S.; ABELL, K.J.; ULYSHEN, M.D.; VAN DRIESCHE, R.G. Population dynamics of an invasive forest insect and associated natural enemies in the aftermath of invasion: implications for biological control. Journal of Applied Ecology, v.52, p.1246-1254, 2015. DOI: 10.1111/13652664.12485.

DUARTE, F.; CAlVO, M.V.; BORGES, A.; SCATONI, I.B. Geostatistics and geographic information systems to study the spatial distribution of Grapholita molesta (Busck) (Lepidoptera: Tortricidae) in peach fields. Neotropical Entomology, v.44, p.319-327, 2015. DOI: 10.1007/s13744-015-0288-3. 
FERREIRA, E.; ZIMMERMANN, F.J.P.; SANTOS, A.B. dos; NEVES, B.P. O percevejo-do-colmo na cultura do arroz. Goiânia: Embrapa-CNPAF, 1997. 43p. (Embrapa-CNPAF. Documentos, 75).

HELDWEIN, A.B.; BURIOL, G.A; STRECK, N.A. O clima de Santa Maria. Ciência \& Ambiente, v.38, p.43-58, 2009.

HOWE, G.A.; JANDER, G. Plant immunity to insect herbivores. Annual Review of Plant Biology, v.59, p.41-66, 2008. DOI: 10.1146/annurev.arplant.59.032607.092825.

GUNDOGDU, K.S.; GUNEY, I. Spatial analyses of groundwater levels using universal kriging. Journal of Earth System Science, v.116, p.49-55, 2007. DOI: 10.1007/s12040-007-0006-6.

JOHNSTON, K.; VER HOEF, J.M.; KRIVORUCHKO, K.; LUCAS, N. ArcGIS 9: using ArcGIS geostatistical analyst. Redlands: Esri Press, 2001. 306p.

KLEIN, J.T.; REDAELLI, L.R.; BARCELLOS, A. Occurrence of diapause and the role of Andropogon bicornis (Poaceae) tussocks on the seasonal abundance and mortality of Tibraca limbativentris (Hemiptera: Pentatomidae). Florida Entomologist, v.95, p.813818, 2012. DOI: 10.1653/024.095.0401.

KRINSKI, D.; FOERSTER, L.A. Damage by Tibraca limbativentris Stål (Pentatomidae) to upland rice cultivated in Amazon Rainforest Region (Brazil) at different growth stages. Neotropical Entomology, v.46, p.107-114, 2017. DOI: 10.1007/ s13744-016-0435-5.

MACHADO, R.C.M.; SANT'ANA, J.; BLASSIOLIMORAES, M.C.; LAUMANN, R.A.; BORGES, M. Herbivoryinduced plant volatiles from Oryza sativa and their influence on chemotaxis behaviour of Tibraca limbativentris stal. (Hemiptera: Pentatomidae) and egg parasitoids. Bulletin of Entomological Research, v.104, p.347-356, 2014. DOI: 10.1017/ S0007485314000133.

MEDEIROS, L.; MEGIER, G.A. Ocorrência e desempenho de Euschistus heros (F.) (Heteroptera: Pentatomidae) em plantas hospedeiras alternativas no Rio Grande do Sul. Neotropical Entomology, v.38, p.459-463, 2009. DOI: 10.1590/S1519566X2009000400003.

NGUYEN-NGOC, D.; NGUYEN-HUU, T.; AUGER, P. Effects of fast density dependent dispersal on pre-emptive competition dynamics. Ecological Complexity, v.10, p.26-33, 2012. DOI: 10.1016/j.ecocom.2011.12.003.

PANIZZI, A.R. Growing problems with stink bugs (Hemiptera: Heteroptera: Pentatomidae): species invasive to the U.S. and potential Neotropical invaders. American Entomologist, v.61, p.223-233, 2015. DOI: 10.1093/ae/tmv068.

PANIZZI, A.R. Wild hosts of pentatomids: ecological significance and role in their pest status on crops. Annual review of entomology, v.42, p.99-122, 1997. DOI: 10.1146/annurev. ento.42.1.99.
PASINI, M.B.P.; LÚCIO, A.D.; CARGNELUTTI FILHO, A. Semivariogram models for estimating fig fly population density throughout the year. Pesquisa Agropecuária Brasileira, v.49, p.493-505, 2014. DOI: 10.1590/S0100-204X2014000700001.

PASINI, M.B.P.; LÚCIO, A.D.; RIBEIRO, A.L.P. Populations of phytophagous bugs influenced by crop background and wild plants. Revista de Ciências Agrárias, v.58, p.410-417, 2015. DOI: 10.4322/rca.1848.

PAZINI, J. de B.; BOTTA, R.A.; SEIDEL, E.J.; SILVA, F.F. da; MARTINS, J.F. da S.; BARRIGOSSI, J.A.F.; RÜBENICH, R. Geostatistics applied to the study of the spatial distribution of Tibraca limbativentris in flooded rice fields. Ciência Rural, v.45, p.1006-1012, 2015. DOI: 10.1590/0103-84cr20140841.

REUNIÃO TÉCNICA DA CULTURA DO ARROZ IRRIGADO, 30., 2014, Bento Gonçalves. Arroz irrigado: recomendações técnicas da pesquisa para o sul do Brasil. Santa Maria: Sosbai, 2014. 189p.

ROSADO, J.F.; PICANÇO, M.C.; SARMENTO, R.A.; PEREIRA, R.M.; PEDRO-NETO, M.; GALDINO, T.V.S.; SARAIVA, A. de S.; ERASMO, E.A.L. Geostatistics as a tool to study mite dispersion in physic nut plantations. Bulletin of Entomological Research, v.105, p.381-389, 2015. DOI: 10.1017/S0007485315000310.

SCIARRETTA, A.; TREMATERRA, P. Geostatistical tools for the study of insect spatial distribution: practical implications in the integrated management of orchard and vineyard pests. Plant Protection Science, v.50, p.97-110, 2014.

SMANIOTTO, L.F.; PANIZZI, A.R. Interactions of selected species of stink bugs (Hemiptera: Heteroptera: Pentatomidae) from leguminous crops with plants in the Neotropics. Florida Entomologist, v.98, p.7-17, 2015. DOI: 10.1653/024.098.0103.

SOARES, V. P.; ZANETI, L. Z.; SANTOS, N. T.; LEITE, H. G. Análise espacial da distribuição de cigarras (Quesada gigas Oliver) em povoamentos de paricá (Schizolobium amazonicum Huber ex Ducke) na região de Dom Eliseu, PA. Revista Árvore, v.32, p.251-258, 2008. DOI: 10.1590/S0100-67622008000200008.

TRUJILLO, M.R. Contribuição ao conhecimento do dano e biologia de Tibraca limbativentris Stal, 1860 (Hemiptera- Pentatomidae) praga da cultura do arroz. 1970. 63p. Tese (Mestrado) - Escola Superior de Agricultura Luiz de Queiróz, Piracicaba.

WEBSTER, R.; OLIVER, M.A. Geostatistics for environmental scientists. $2^{\text {nd }}$ ed. [S.1.]: John Wiley \& Sons, 2007. 315p. DOI: 10.1002/9780470517277.

YAMAMOTO, J.K.; LANDIM, P.M.B. Geoestatística: conceitos e aplicações. São Paulo: Senac, 2013. 215p.

ZIMBACK, C.R.L. Análise espacial de atributos químicos de solo para o mapeamento da fertilidade do solo. 2001. 114p. Tese (Livre-Docência) - Faculdade de Ciências Agronômicas, Universidade Estadual Paulista, Botucatu.

Received on January 1, 2017 and accepted on July 6, 2017

Pesq. agropec. bras., Brasília, v.53, n.3, p.265-278, Mar. 2018

DOI: $10.1590 / \mathrm{S} 0100-204 X 2018000300001$ 